\title{
ROLE OF CAESAREAN SECTION IN ECLAMPSIA
}

\author{
Bhupesh H. Gaikwad', Rahul P. Maskar²
}

${ }_{1}^{1}$ Associate Professor, Department of Obstetrics and Gynaecology, R. C. S. M. Govt. Medical College, Kolhapur.

${ }^{2}$ Assistant Professor, Department of Obstetrics and Gynaecology, R. C. S. M. Govt. Medical College, Kolhapur.

\section{ABSTRACT}

The disease "Eclampsia" is known since the birth of modern medicine and even before that. The Syndrome of pre-eclamptic toxaemia is known for last $200 \mathrm{yrs}$. Still, the disease continues to hunt the obstetrician and with considerable severity. The clinical management of eclampsia 'has gone through' many changes and achieved good results with the introduction of new regimes. The present study is undertaken to find out/access the Role of Caesarean section in eclampsia and to study the outcome of caesarean section with reference to maternal mortality. Maternal morbidity, perinatal mortality and perinatal survival.

\section{KEYWORDS}

Caesarean Section, Eclampsia, Maternal Mortality, Maternal Morbidity, Perinatal Mortality, Perinatal Survival.

HOW TO CITE THIS ARTICLE: Gaikwad BH, Maskar RP. Role of caesarean section in eclampsia. J. Evolution Med. Dent. Sci. 2016;5(43):2654-2656, DOI: $10.14260 /$ jemds/2016/621

\section{INTRODUCTION}

The term "Eclampsia" is derived from a Greek word meaning "like a flash of lightening" Alexander Hamilton (1791) described eclampsia as a disease, which always attended with the utmost hazard and frequently kills the woman like a fit of apoplexy.

Eclampsia is a life-threatening emergency that continues to be a major cause of maternal and perinatal mortality worldwide. Maternal mortality varies widely at different places with almost identical management indicating that there may be some important differences in socio-economic condition of the nation and the quality of obstetric care.

It is reported throughout the world that the incidence of Eclampsia is gradually declining, but it is still a menace in India and other developing countries. In India, maternal mortality and morbidity from eclampsia is very high. The figures range from $8-14 \%$. A low maternal mortality of 2.2 was reported by Menon. The perinatal mortality ranges from $14.6 \%$ to $47.4 \%$.

The clinical management of eclampsia 'has gone through' many changes and achieved good results with the introduction of new regimes.

The present study is undertaken to find out/access the Role of Caesarean section in eclampsia and to study the outcome of caesarean section with reference to maternal mortality. Maternal morbidity, Perinatal mortality and Perinatal survival (Eclampsia cases with reference to its).

- Incidence,

- Primigravida which is affected more,

- Management of choice - Caesarean section,

- Mode of delivery affecting maternal and perinatal outcome.

- Major maternal complication and mode of delivery.

Financial or Other, Competing Interest: None.

Submission 28-11-2015, Peer Review 30-11-2015,

Acceptance 09-01-2016, Published 27-05-2016.

Corresponding Author:

Dr. Bhupesh H. Gaikwad,

Flat No. 704, HR4, Building,

Punya Parra, Near Apple Hospital,

Kolhapur-416005.

E-mail: bhupeshgaikwad@rediffmail.com

DOI: $10.14260 /$ jemds/2016/621
- Eclampsia/imminent eclampsia as an indication for caesarean section, admission discharge interval and mode of delivery of eclampsia patients.

\section{MATERIAL AND METHODS}

A total no. of 118 cases of eclampsia admitted to RCSM, GMC, Kolhapur.

\section{Inclusion Criteria}

- Patients with antepartum convulsion.

- Patients with intrapartum convulsion.

- Patients with postpartum convulsion till 8 days.

- All patients referred to the hospital, and

- Patients on Pritchard's regime.

\section{Exclusion Criteria}

- Patients with convulsion due to a cause other than eclampsia. Eg. Epilepsy, Cerebral venous thrombosis.

On admission, detailed history was taken from the attendant and clinical examination was done. Particular reference was given to the following points-

1. Name, address, age, occupation of the patient, occupation of her husband, socio-economic status.

2. Detailed history regarding Registration of case, ANC check-up, previous history of PIH/PET/Eclampsia, $\mathrm{PIH} / \mathrm{PET} /$ Eclampsia in this pregnancy was taken.

3. Duration of gestation.

4. Detailed history of eclampsia with reference to

a. H/O Labour pains

b. H/O PV Bleeding

c. H/O PV Leaking

d. Premonitory symptoms - Headache, Giddiness, Blurring of Vision, Nausea/Vomiting, Epigastric pain, Scanty urine.

e. Convulsions:

1. Total no. of convulsions - after admission

2. Time of onset of 1 st convulsion

3. Interval between convulsions

4. History of loss of consciousness

5. Period of loss of consciousness after convulsion.

6. Interval between two convulsions.

7. Any treatment outside.

8. Time interval between 1 st convulsion and admission. 
5. A detailed obstetric history, menstrual history, past history, family history, personal history and contraception history were noted. A detailed history taken on obst exam.

\section{INTERVENTION}

1. General nursing care, fluid and electrolyte balance were maintained, U/O was monitored with an indwelling catheter.

2. Medical management.

a. Anticonvulsants: To keep the patient sedated and to prevent convulsion, MgSO4 therapy was used. Pritchard's Protocol: (High dose regime).

b. Antihypertensive.

c. Antibiotics.

3. Obstetric management.

An attempt was made in each case after the control fits to find out if the patient was in labour, whether the cervix was favourable for induction.

If the cervix was favourable and the CPD was r/o labour, was induced with either oxytocin drip, ARM, PGE, etc. and patient was allowed for vaginal delivery.

II stage was shortened by assisting the delivery by forceps or vacuum extractor whenever indicated. Lower segment caesarean section was done for eclampsia per se in cases of unfavourable cervix, status eclampticus and if the convulsions recurred and were not controlled in 10-12 hrs. after starting the treatment in favour of maternal condition.

\section{Follow-Up}

All the mothers were followed up for evidence of - Decrease in BP.

- $\quad$ Evidence of proteinuria.

- Any other complication of eclampsia.

All the babies delivered were followed up during neonatal period for complications.

Statistical Analysis: Has been done using the Chi- Square test. Where $-0=$ Observed

$\mathrm{E}=$ Expected

The total no. of 5876 deliveries have been conducted, out of which 118 patients had eclampsia.

\begin{tabular}{|c|c|c|}
\hline Mode of Delivery & No. of Cases & \% \\
\hline A) Vaginal & 68 & 57.62 \\
\hline $\begin{array}{c}\text { Full term normal } \\
\text { delivery preterm }\end{array}$ & 1850 & $\begin{array}{l}26.47 \\
73.52\end{array}$ \\
\hline $\begin{array}{c}\text { B) Lower segment } \\
\text { caesarean section }\end{array}$ & 50 & 42.37 \\
\hline Full term & 26 & 52.00 \\
\hline Preterm & 24 & 48.00 \\
\hline
\end{tabular}

\begin{tabular}{|c|c|c|}
\hline $\begin{array}{c}\text { First Convulsion - } \\
\text { Admission Interval }\end{array}$ & $\begin{array}{c}\text { All Cases of } \\
\text { Eclampsia }\end{array}$ & $\begin{array}{c}\text { Maternal } \\
\text { Mortality }\end{array}$ \\
\hline (A) Vaginal & & \\
\hline $0-6$ & 55 & - \\
\hline $7-12$ & 11 & 1 \\
\hline $13-18$ & 2 & 1 \\
\hline $19-24$ & - & - \\
\hline$>24$ & - & - \\
\hline (B) Lower Segment & & \\
\hline
\end{tabular}

\begin{tabular}{|c|c|c|}
\hline Caesarean Section & & \\
\hline $0-6$ & 36 & - \\
\hline $7-12$ & 10 & - \\
\hline $13-18$ & 4 & 1 \\
\hline $19-24$ & - & - \\
\hline$>24$ & - & - \\
\hline
\end{tabular}

It is observed that maternal mortality increases with increase in first convulsion - admission interval.

\section{Maternal Mortality in Relation to Type of Eclampsia}

\begin{tabular}{|c|c|c|c|c|}
\hline \multirow{2}{*}{$\begin{array}{c}\text { Types of } \\
\text { Eclampsia }\end{array}$} & \multicolumn{2}{|c|}{ All Cases } & \multicolumn{2}{|c|}{$\begin{array}{l}\text { Maternal } \\
\text { Mortality }\end{array}$} \\
\hline & $\begin{array}{l}\text { No. of } \\
\text { Cases }\end{array}$ & $\%$ & $\begin{array}{l}\text { No. of } \\
\text { Cases }\end{array}$ & $\%$ \\
\hline \multicolumn{5}{|l|}{$\begin{array}{l}\text { A) Vaginal } \\
\text { delivery }\end{array}$} \\
\hline Antepartum & $\begin{array}{c}35 \\
(1 \\
\text { Postpartum } \\
\text { has } \\
\text { recurrence) } \\
\end{array}$ & $\begin{array}{l}\frac{35}{68} \\
\times 100 \\
=51.47\end{array}$ & 1 & $\frac{1}{35}=2.85$ \\
\hline Intrapartum & $\begin{array}{c}31 \\
(1 \\
\text { Postpartum } \\
\text { has } \\
\text { recurrence) }\end{array}$ & $\begin{array}{l}\frac{31}{68} \\
\times 100 \\
=45.58\end{array}$ & 1 & $\frac{1}{31}=3.32$ \\
\hline Postpartum & 年 & $\begin{array}{l}\frac{2}{68} \\
\times 100 \\
=2.94\end{array}$ & - & 0 \\
\hline \multicolumn{5}{|l|}{$\begin{array}{c}\text { B) } \\
\text { Caesarean } \\
\text { Section } \\
\end{array}$} \\
\hline Antepartum & $\begin{array}{c}26 \\
\text { (5 } \\
\text { Postpartum } \\
\text { has } \\
\text { recurrence) }\end{array}$ & $\begin{array}{l}\frac{26}{50} \\
\times 100 \\
=52\end{array}$ & 1 & $\frac{1}{26}=3.8$ \\
\hline Intrapartum & 24 & $\begin{array}{l}\frac{24}{50} \\
\times 100 \\
=48 \\
\end{array}$ & 1 & 0 \\
\hline Postpartum & 0 & $0=0$ & - & 0 \\
\hline
\end{tabular}

It is observed that there were 2 deaths in group $A$ and 1 death in group B. Both these antepartum and intrapartum cases have postpartum recurrence.

\section{Maternal Mortality in Relation with No. of Convulsions}

\begin{tabular}{|c|c|c|c|}
\hline $\begin{array}{c}\text { No. of } \\
\text { Convulsion }\end{array}$ & $\begin{array}{c}\text { Mode of } \\
\text { Delivery }\end{array}$ & $\begin{array}{c}\text { Maternal } \\
\text { Mortality }\end{array}$ & $\mathbf{\%}$ \\
\hline 1 & Vaginal 22 & - & 0 \\
\hline & C.S. 15 & - & 0 \\
\hline 2 & Vaginal 21 & - & 0 \\
\hline & C.S. 17 & - & 0 \\
\hline 3 & Vaginal 14 & - & 0 \\
\hline & C.S. 08 & - & 0 \\
\hline 4 & Vaginal 04 & 1 & 12.50 \\
\hline & C.S. 04 & - & 0 \\
\hline 5 & Vaginal 03 & - & 0 \\
\hline & C.S. 04 & 1 & $16.66 \%$ \\
\hline 6 & Vaginal 02 & - & 0 \\
\hline
\end{tabular}




\begin{tabular}{|c|c|c|c|}
\hline & C.S. & - & 0 \\
\hline 7 & Vaginal 01 & - & 0 \\
\hline & C.S. & - & 0 \\
\hline 8 & Vaginal & - & 0 \\
\hline & C.S. 02 & - & 0 \\
\hline 9 & Vaginal 01 & 1 & $100 \%$ \\
\hline & C.S. & - & 0 \\
\hline 10 & Vaginal & - & 0 \\
\hline & C.S. & - & 0 \\
\hline
\end{tabular}

It is observed that maternal mortality is associated with increase in no. of convulsions.

\section{Showing Causes of Maternal Mortality}

There were 3 maternal deaths, each case due to multiple causes due to eclampsia.

\begin{tabular}{|c|c|c|c|c|c|c|c|}
\hline No. & $\begin{array}{c}\text { Mode of } \\
\text { Delivery }\end{array}$ & $\begin{array}{c}\text { Causes } \\
\text { PPH }\end{array}$ & Shock & HELLP & DIG & CCF & $\begin{array}{c}\text { Aspiration } \\
\text { Pneumonitis }\end{array}$ \\
\hline 1 & C.S. & $\sqrt{ }$ & $\sqrt{ }$ & & $\sqrt{ }$ & & \\
\hline 2 & Vaginal & $\sqrt{ }$ & & $\sqrt{ }$ & & & $\sqrt{ }$ \\
\hline 3 & Vaginal & $\sqrt{ }$ & $\sqrt{ }$ & $\sqrt{ }$ & $\sqrt{ }$ & $\sqrt{ }$ & \\
\hline
\end{tabular}

Of the 3 maternal deaths all 3 had PPH, 2 developed shock, 2 developed HELLP, 2 developed DIG, 1 developed Aspiration pneumonitis.

Distribution of Perinatal Deaths in Eclampsia, Convulsion Onset-Delivery Interval

\begin{tabular}{|c|c|c|c|}
\hline $\begin{array}{c}\text { Convulsion Onset } \\
\text { \& Delivery Interval (hrs.) }\end{array}$ & $\begin{array}{c}\text { No. of } \\
\text { Cases }\end{array}$ & $\begin{array}{c}\text { Vaginal } \\
\text { Delivery }\end{array}$ & C.S. \\
\hline$<6$ & 12 & 7 & 5 \\
\hline $6-12$ & 9 & 5 & 4 \\
\hline $13-24$ & 20 & 19 & 1 \\
\hline 24 & 3 & 3 & 0 \\
\hline
\end{tabular}

\section{DISCUSSION}

The incidence in the present study is $2 \%$ as against $2.79 \%$ and $1.85 \%$ reported by Arup Kumar Majhi (2001). ${ }^{1}$ and Nobis P (2002). ${ }^{2}$ respectively. The higher incidence in the present study is due to lack of proper antenatal care and also because the study is undertaken in a referral hospital.

In the present study, convulsion onset delivery interval is directly proportional to maternal and perinatal mortality. Similar observations have been made by Nanda Smita (1989). ${ }^{3}$ and Swain S (1993).

The perinatal mortality increases when the interval between the first fit and the delivery increases due to prolonged exposure to intrapartum asphyxia.

The rate of maternal and perinatal mortality in antepartum eclampsia are comparatively much lesser than the findings of Varawalla Nermee Y (1978). ${ }^{4}$
According to Datta and Biswas (1978). ${ }^{5}$ perinatal mortality rate in antepartum eclampsia was $49.4 \%, 32.9 \%$ in intrapartum.

Out of 118 cases $57.62 \%$ cases delivered vaginally, while $42.37 \%$ cases delivered by caesarean section. Maternal mortality of $112.94 \%$ was observed in vaginal delivery group, while it was $2 \%$ in caesarean section group.

There is no general agreement as to the mode of delivery in eclampsia. Menon (1961). ${ }^{6}$ and Worley (1984) recommended vaginal delivery in eclampsia reserving C.S. only for obstetrical reasons. On the other hand, Pritchard (1985), Chesley (1978) have favoured C.S. to reduce the maternal and perinatal mortality.

\section{ABBREVIATIONS}

- PPRC - Postpartum Recurrence of Convulsion.

- P - Preterm.

- $\quad$ LBW - Low Birth Weight Baby.

- IUGR - Intrauterine Growth Retardation.

- IA - Intrapartum Asphyxia.

- C.S. - Caesarean Section.

- Vag - Vaginal Delivery.

- UC - Uncontrolled Convulsion.

- $\quad$ CPD - Cephalo-Pelvic Disproportion.

- $\quad$ FD - Fetal Distress.

- UCx - Unfavourable Cervix.

- $\quad$ PC/CPD - Previous LSCS with CPD.

- AP - Abruptio Placentae.

- OC - Oblique lie.

- DIC - Disseminated Intravascular Coagulation.

- $\quad$ PPH - Postpartum Haemorrhage.

- APP - Aspiration Pneumonitis.

- $\quad$ CCF - Congestive Cardiac Failure.

- Uncon - Unconsciousness.

\section{REFERENCES}

1. Arup Kumar Majhi, Parth Sarathi Chakraborty, Asima Mukhopadhyay. Eclamsia-present scenario in a referral medical college hospital. J Obstet Gynaecol India 2001;51(3):143-7.

2. Nobis PN. Maternal outcome in eclampsia. Asian J Obstet Gynaec Practice 2002;6(1):25-8.

3. Nanda Smiti, Jai Bhagwan Sharma, Nirmal Gulati. Perinatal mortality in eclampsia. J Obstet Gynaecol Ind 1989;39:792-4.

4. Varawalla Nermee Y, Sharad Ghmande, Kumud M Ingle. A five year analysis of eclampsia. J Obstet Gynaecol Ind 1989;39:513-5.

5. Mudaliar AC, Krishna Menon MK. Clinical obstetrics India. Orient Longman Ltd 1997;133-54.

6. Menon MKK. The evolution of the treatment of eclampsia. J Obset Gynaec Brit C' Wealth 1961;68(3):417-26. 